\title{
Grammatical Errors Made by The Eleventh Grade Students in English Argumentative Writing
}

\author{
Yulian Juita Ekalia \\ Universitas Katolik Indonesia Santu paulus Ruteng, Jl. Ahmad Yani 10 Manggarai NTT, Indonesia
}

\{enuyulian@gmail\}

\begin{abstract}
Grammatical errors that the English learners make in language learning are difficult to be avoided. To reduce those errors the learners should pay more attention in mastering grammar so it will not be fossilized in their minds. This paper aims at investigating grammatical error made by Eleventh Grade Students in English argumentative writing. This study is a descriptive qualitative by collecting data from students of Saint Hendrikus Senior High School writing test. The result shows that the course students with additional English Course do not make many errors in argumentative essay rather than another group. However, the frequency of the error is not too wide in every item between two groups. The misuse of using tense has almost the same frequency; $60 \%$ and $57 \%$ between two groups and it happened because the less comprehension of using adverb of time in a sentence. The less error happened only on using gerund $0 \%$ and $3 \%$.
\end{abstract}

Keywords: Grammatical error, frequency of error, Argumentative Writing

\section{Introduction}

English is a tool for multicultural societies and cross culture understanding in order to have a better communication skill among others. Regarding the importance of English language, the learners need to have a good competence in four skills (speaking, listening, reading or writing). Among these four skills, writing is indicated as the most difficult part in mastering English, because it doesn't only need grammatical and rhetorical devices but also conceptual and judgmental elements [1]. In spite of its difficulty, writing is an important part to deliver the ideas and to underscore that someone is really literate. Being able to write in English is one of the goals that the students need to achieve. In order to achieve a well-structured writing, students must be able to mix their knowledge [2].

Learning English as a foreign language is still a big problem because English itself is not an everyday language both in written and in spoken type. However, due to its importance as an international language, students encourage themselves to master the language. The spirit to be fluent in English is sometimes supported by having private English teacher, taking course outside the classroom and leaning English subject in the classroom as designed in the curriculum. But among those students' efforts and facilities, the errors or mistakes are still undeniable and unaware in which they do not pay attention to grammar correctness. 
The grammatical errors are still encountered by the students in a Senior High School. Making error and mistake in writing English are commonly done by the second and foreign language students. Error is actually different from mistake. [3] Defined that a mistake refers to performance error or a 'slip' while an error is a noticeable deviation done by a person reflecting the competence of the learner meant a random guess. It can be concluded that an error is a deviation which is made by the students because they don't recognize the rules so they keep creating errors repetitively in writing.

Moreover, writing argumentative is the one of the five types of essay that students need to master. According to [4] that there are five types of essays learned by the college students. They are narrative essay, descriptive essay, cause and effect essay, argumentative essay, and comparison and contrast essay. The idea of selecting argumentative essay for this research is through argumentative writing the students are expected to be able to express their ideas, state their opinion, and express their thoughts in writing so that they can provide the evidence and sample about the common issues about their surroundings.

In addition, writing an argumentative essay has four parts, namely, introduction, supporting arguments, opposing arguments, and conclusion. In the introduction part, it is important to take on the issue with a thesis sentence and give arguments to support the case. Then, in the supporting argument part, it is good to start by the general issue and identify supporting argument or opinion, use biased language that supports argument and put the reader in the right frame to accept the argument. Opposing argument part addresses the arguments presented by those opposing claim by pointing out problems with their claims. Conclusion involves the restating what the argument is and summarize what the writer has done in the essay to support it. Here, a discussion is needed related to the implications of the argument.

Furthermore, writing about grammatical error is not a new thing to be discussed. Several researchers had conducted the studies dealing with the related topics. [5], for example, conducted a grammatical error analysis on the students' English writing. Other writers like [6] conducted similar research. However, they are different in terms of the types of text analysed and the respondents investigated. [5] studied the university students of UNSIQ Wonosobo, but [7] studied Jambi University students' grammatical errors. It's different study conducted by [8] focusing on identifying the types of grammatical errors on the students 'narrative writing. The next researcher comes from [9]. Her study focuses on the comparative error analysis in English writing made by different levels.

The study analyses the error types, the frequency of errors and the similarities and difference of errors first, second-, and third-year learners. There are types of errors namely lexical errors and syntactical errors, eight categories and twenty -seven error cases. The secondyear learners made the most frequent error $46 \%$, while first year learners produced $10 \%$ frequent error and the third learners made $13 \%$ of frequent error. Although her focus on comparative error analysis in writing and having a similarity in source of data on the other hand previous study has the difference with the present study which is in the concept of investigation. The previous study explores about the errors types and similarities and difference of errors however the present study investigate a frequent of errors in students'argumentative writing.

Based on that explanation above, the researcher is interested in finding out the frequency of grammatical error that was done by the regular and course students of Saint Hendrikus Senior High School Surabaya in argumentative writing test. It is expected that the the writer is able to figure out the errors made by the eleventh-grade students as well as finding out the best way to overcome the problems. 


\section{Research Methods}

The research type was a descriptive qualitative research. [10] defines that descriptive research is a research with the view to collect the information and to describe about a variable or a phenomenon. The researcher utilized the cluster random sampling techniques to select group of population a sample randomly. According to [11] the sample size of descriptive research should be at least $10 \%$ of the population. There were basically 65 students involved in this study.

However, the researcher chose some of them randomly in order to make the population smaller. In the end, there were 44 students taking part in it. From these 44 students, 22 of them are taking an additional English course and the rest number are not. Both categories of students did an argumentative writing, and this study is conducted to compare the number of grammatical error that both categories of students made. The data collection is obtained by giving an argumentative writing test. To respond the first question in research question, the data were analysed in some steps. First, the researcher deleted the students 'name in their writings. After that, the researcher gave a code in students 'paper. The frequency of error types, it based on [12] to find out the frequencies of errors types by percentage. They provided the formula.

\section{Results and Discussion}

The result of this research shows that both categories of students made grammatical error in writing and the frequency of making error is almost the same in every item like modal verb, misuse of tense, word choice error. The small error happened in term of using gerund and interlanguage as shown in this table 3.1 below

Table 1. Frequency Of Errors Made By Students Without And With Additional English Course

\begin{tabular}{|c|c|c|c|c|}
\hline No & Item & $\begin{array}{l}\text { Freque } \\
\text { made b } \\
\text { Englist }\end{array}$ & $\begin{array}{l}\text { of Error } \\
\text { dditional } \\
\text { urse Students }\end{array}$ & $\begin{array}{l}\text { Frequency of error } \\
\text { made by non } \\
\text { additional English } \\
\text { English Students }\end{array}$ \\
\hline 1 & Modal Verb & & $10 \%$ & $14 \%$ \\
\hline 2 & Gerund & & $0 \%$ & $3 \%$ \\
\hline 3 & Misuse of Te & & $60 \%$ & $57 \%$ \\
\hline 4 & Singular-Plur & 1 Form & $20 \%$ & $17 \%$ \\
\hline 5 & Inter-langu & & $2 \%$ & $8 \%$ \\
\hline
\end{tabular}

\section{Modal Verbs}

In English learning, there are a number of modal verb namely can-could, must, may-might, shall-should, will-would, has/have/had/ought to. All these modal verbs are followed by infinitive verb or familiar known as verb 1. Many grammatical errors appear in the work of students in argumentative are using gerund which means, after modal-verb, the form of gerund is followed. Other sentences are followed by verb- 2 or past form. Interestingly, these errors are mostly done by the course students with additional English Course. To identify what the errors of the students, the following are examples:

a. Education shall become a focus of many people 
b. Many people can use internet to search information

c. We must select all the websites in using internet

d. Many people must realize the importance of internet

\section{Gerund}

Gerund is a noun of English by putting the form of suffix-ing in an infinitive verb. The function of gerund can be various as subject, object, a complement of a sentence. However, this error is not so common in the work of students in which the students with additional English course has no error at all and only a few of another group. The errors that appear are:

a. I like use technology

b. Many people using internet in their daily life.

\section{Inter-language}

Inter-language error that influenced by students' first language is less common in both groups but there is still a number of errors in the group of students without additional English course. Those errors are:

a. I accept about learning English is importance

b. I lazy to learning English because I think is boring so my English not good.

These errors occur because of the students assume that there is a similar pattern between source language and target language in making a sentence. The example of sentence (b) is a proof how the students deal with that assumption. Besides, the error also happens due to the students' translation from source language to target language in which they do not pay attention to the word choice of an English word. They just transfer it literally without referring it to the context of the target language.

\section{Singular-plural form}

English has its own regular rules in using singular-plural forms in a sentence. Most of nouns are pluralized by adding suffix $-s$ or -es. Only a few of nouns are formed by specific rule like mouse-mice, foot-feet etc. The second number students' errors in both categories in this study are the use of singular-plural form. The grammatical errors made by the students are:

a. One of the modern technologies in this world

b. Many students are using laptop in the class

c. When I was a kid, I often read many books

\section{Misuse of Tenses}

The most common error of students from both categories in this research appears in the misuse of tenses. It can be compared as shown in the above table $60 \%$ and $57 \%$. In English learning, the use of tense involves the adverb of time of the action in order to know whether the sentence belong to the past, present or future action. The errors that the students made in argumentative writing happened mostly because the shift of a tense without a clear reason at all and the confusion of using adverb of time in a sentence. Some kind of errors from the students in the argumentative writing from both categories of students can be seen as follows:

a. Now I studied at saint Hendrikus School.

b. Education was the main things for us in the future

c. About ten years ago we still use.

Another cause of error in term of using tense in students' argumentative writing is the misuse of the change of irregular/regular verbs in English. Almost all of the error makers from 
both categories of students do not pay attention to the use of the change like become-becamebecome. Some errors that appear in the students writing are:

a. I keep learning when I was ten years old.

b. My parents force me to have additional English Course when I was a little.

c. I want to become a journalist.

Those verbs tense could occur due to the structure of English and students ${ }^{6}$ mother language are different. It is shown the verbs tense here occupied the highest numbers of errors in this research. In line with this finding, the studies were conducted by [7], and [13] had the same result with the present study. The result was the highest amount of errors occured in misuse of grammar especially verb-tense category. Furthermore, this finding of study is also harmonious with[9]. She said that most of the learners made errors on syntactical errors especially about " modal verbs". It means that learners had lack of English Grammar and they could not use tenses in the appropriate situation. Moreover, they created the new form that is similar in the English Grammar but it is incorrect. Lexical errors are one problem for learners' English writing because they didn't remind some spelling due to the different of letters of their mother language.

Another contrasting result was found by [5]whose research finding showed that the students are still difficult to identify the correct grammatical form in building sentences. The causes of errors are both interlingual and intralingual. However, more errors are caused by inter lingual which are related to the learning strategy of the target language. Students are still unable to make a good composition in this language. The reserchers are able to conclude that it is because an interlingual transfer, students are still influeced by their native linguistic system which directs them to creating some errors.

\section{Conclusion}

Grammatical errors are a common mistake made by students at any level even for adult as long as English is their second language. In order to have a good comprehension of English, it is essential to master grammar as main focus of learners because the errors are often made in writing. Mastering grammar is a way of minimalizing a number of errors in speaking, listening and writing. If the students/learners invest a lot of time in learning grammar in general and tenses in details, it is better to arrange the sentence.

The finding that the grammatical errors of both categories of Saint Hendrikus students indicates the misuse of grammar as the main problem of the students especially tenses. The researcher expects that all the causes that are found in this study can focus on the teacher when delivering English materials.

\section{References}

[1] H. J.B, Longman Handbooks for Language Teachers: Writing English Language Test. New York: Longman, Inc., 1988.

[2] J. Harmer, How to Teach Writing. Essex. New Jersey: Pearson Education ESL., 2004.

[3] H. D. Brown, "Language assessment: Principles and classroom practices," in review, New York: Pearson Education, Inc, 2004.

[4] M. \& J. W. Kathleen, How to Write Essays \& Assignments, UEL 2nd Ed. Prentice Hall, 2014. 
[5] Christina, "Grammatical error analysis of student's writing in the English department at faculty of Language and literature," Master Pro., UNSIQ Wonosobo Semarang: Diponegoro University Faculty of Humanities, 2016.

[6] M. U, Krista and L, "Students'Grammar Mistakes and Effective Teaching Strategies.," Int. J. Teach. Educ., vol. 3 (1), pp. 58-75, 2015.

[7] H. S. M. and M. Reni, Heryanti, "THE ANALYSIS OF COMMON GRAMMATICAL ERRORS IN WRITING NARRATIVE ESSAY OF ENGLISH STUDY PROGRAM STUDENTS AT JAMBI UNIVERSITY,” J. Pendidik. dan Pengajaran, vol. 4 (2), pp. 83-92, 2017.

[8] Yasir Bdaiwi Jasim Al-Shujairi \& Helen Tan, "Grammar Errors in the Writing of Iraqi English Language Learners,” Int. J. Educ. Lit. Stud., vol. 5, no. 4, 2017.

[9] S. Nokthavivanh, "Comparative Error Analysis in English Writing By First, Second, and Third Year Students of English Department of Faculty of Education at Champasack University.," 2016.

[10] S. Arikunto, Prosedur Penelitian Suatu Pendekatan Praktik. Jakarta: Pt. Rineka Cipta.

[11] G. and P. A. L.R, Educational Research: Competencies for Analysis and Application. New Jersey: Prentice-Hall Company., 2009.

[12] E. \& L. A. Hatch, The Research Manual: Design and Statistics for Applied Linguistics. Los Angeles: Heinle \& Heinle Publishers., 1991.

[13] D. I.,Kamlasi \& Nokas, "Grammatical Errors in Writing of The Second Class Students of SMA Kristen 1 Soe,” J. English Lang. Lit. Teach., vol. 1 No.1, p. 130, 2017. 